\title{
MONOGRAFAR EM LIBRAS: BUSCANDO PADRÕES DE ESCRITA EM VÍDEO-REGISTROS ACADÊMICOS ${ }^{1}$
}

\section{MONOGRAPHING IN LIBRAS: LOOKING FOR WRITING STANDARDS IN ACADEMIC VIDEO-RECORDS}

\author{
Cristiane Correia Taveira ${ }^{2}$ \\ Luiz Alexandre da Silva Rosado ${ }^{3}$
}

\begin{abstract}
Resumo: Este artigo é fruto de pesquisa em andamento no Departamento de Ensino Superior do INES (DESU-INES) oriunda da experiência de elaboração de monografias em Libras com alunos de graduação do curso de Pedagogia Bilíngue. O objetivo foi construir esquemas visuais e descritivos que mostrem as características de cenários e dos padrões de linguagens nos fenômenos de interação durante a consecução de monografias em Libras. São feitas considerações a respeito das tensões entre a Libras e a língua portuguesa no processo de construção discursiva do aluno surdo e não-surdo bilíngue, junto ao professor orientador e o tradutor-intérprete, quando esta equipe se vê na tarefa de construir argumentos científicos formais em língua de sinais com registros em vídeo. Procuramos clarear as etapas desse processo, a fim de dar suporte a futuras orientações que envolvam a produção de vídeo acadêmico em Libras. Entre elas estão: o uso de glosas e glossinais, a busca ou criação de novos sinais para conceitos acadêmicos, o trabalho de roteirização, a filmagem-rascunho, a gravação em estúdio profissional e a edição final do material. Algumas regras de produção visual são apresentadas como exemplos de particularidades encontradas pelos pesquisadores. Ao final, desdobramos comportamentos encontrados em campo que envolvem idealizações na produção de monografias em Libras, indicando questões a serem ponderadas por este conjunto de atores: alunos, professores orientadores e banca examinadora.
\end{abstract}

Palavras-chave: Graduando surdo; Educação bilíngue; Língua Brasileira de Sinais; Monografia; Ensino Superior.

\begin{abstract}
This article is the result of ongoing research in the Department of Higher Education of INES (DESU-INES). Emerges from the experience of elaborating monographs in Brazilian Sign Language (Libras) with undergraduate students of the Bilingual Pedagogy course. The objective was to construct visual and descriptive schemas that show the characteristics of scenarios and the patterns of languages in the interaction phenomena during the making of monographs in Libras. Considerations are made about the tensions between Libras and the Portuguese language in the process of discursive construction of the deaf and non-deaf bilingual student, together with the guiding teacher and the translator-interpreter, when this team finds itself in the task of constructing formal scientific arguments in sign language with video records. We seek to clarify the stages of this process in order to support future orientations that involve the production of academic video in Libras. Among them are: the use of glosses and glossinals, the search for or creation of new signs for academic concepts, the writing work, the filming, the professional studio recording and the final editing of the material. Some rules of visual production are presented as examples
\end{abstract}

\footnotetext{
${ }^{1}$ O presente artigo é uma versão revista e ampliada do artigo publicado em 2015 no livro "Educação e Tecnologia: parcerias vol. 4" pelos pesquisadores junto a dois intérpretes do DESU/INES (TAVEIRA et el., 2015). Nos últimos três anos foram publicadas 5 monografias em Libras em que os autores estiveram diretamente envolvidos na produção, o que suscitou novas reflexões e revisões no texto original, ora aqui publicado.

${ }^{2}$ Pedagoga e Doutora em Educação pela Pontifícia Universidade Católica do Rio de Janeiro. Professora Adjunta no Departamento de Ensino Superior do Instituto Nacional de Educação de Surdos, Rio de Janeiro, RJ, Brasil. E-mail: cristianecorreiataveira@gmail.com

${ }^{3}$ Comunicólogo e Doutor em Educação pela Pontifícia Universidade Católica do Rio de Janeiro. Professor Adjunto no Departamento de Ensino Superior do Instituto Nacional de Educação de Surdos, Rio de Janeiro, RJ, Brasil. E-mail: alexandre.rosado@gmail.com
} 
of particularities encountered by the researchers. In the end, we present behaviors found in the research field that involve idealizations in the production of monographs in Libras, indicating questions to be pondered by this group of actors: students, guiding teachers and teacher examiners' bank.

Keywords: Deaf graduating; Bilingual education; Brazilian Sign Language; Monography; Higher education.

\section{A surdo-memória e o renascimento visual da comunidade surda}

Vilém Flusser (2010 [1987]) nos traz a concepção de uma escrita manual e impressa que, em um primeiro momento, paulatinamente colaborou para a descentração da oralidade a-histórica circular, com a construção de um novo acervo de memória para a humanidade através de bibliotecas, arquivos, museus, nos levando à concepção de uma memória-história linear. O mesmo caminho está sendo percorrido agora com as línguas de sinais, que constroem na internet acervos voltados à comunidade surda e não-surda usuária dessas línguas, que propomos chamar de surdo-memória, pouco dependente da escrita alfabética em sua expressão e comunicação.

$\mathrm{O}$ processo de amadurecimento da revolução de Gutenberg e sua prensa tipográfica durou, ao menos, quatro séculos (XVII ao XX). No tempo presente, estamos vivendo um renascimento visual da cultura e comunicação surda, através do compartilhamento crescente de vídeos, acumulados em curto período, menos de 20 anos, a partir da expansão da Web 2.0 (O'REILLY, 2005), das câmeras digitais em smartphones e tablets e dos sites-acervos-redes sociais (Youtube, Facebook, Vimeo, entre outros). As mídias ópticas digitais (KITTLER, 2016) construíram a materialidade para o renascimento visual e cultural da comunidade surda.

Vilém Flusser, um pensador radical das mídias, então prevê que as novas mídias analógicas e digitais terão a potência de sobrepor, ou mesmo substituir, diversos usos até então associados à escrita, como a produção de conhecimentos científicos, as discussões políticas, o fazer poético e a construção filosófica. "Como sabemos, na verdade, que esses grandes escritores (inclusive, o das sagradas escrituras) não teriam preferido filmar ou gravar seus textos?" (FLUSSER, 2010, p. 14)

Repensar o cenário midiático e desafiar noções estabelecidas é um legado flusseriano a que recorremos. Acreditamos que o momento é propício para se analisar uma reconfiguração do cenário midiático com a introdução de mídias ópticas digitais e a forma como a escrita alfabética é repensada e desafiada por uma comunidade surdaestrangeira em relação à oralidade ouvinte predominante. Segundo a visão flusseriana (2013), seria caminhar para a reformulação da nossa percepção, pois a experiência no 
mundo passa a ser regida por outros códigos e convenções, por linguagens e projetos que vão além de uma simples mudança da paisagem dos artefatos técnicos.

Em síntese: o registro dessas mensagens em suportes técnicos possui uma gramaticalidade visual com suas regularidades, as quais pretendemos mapear, e uma forma de comunicação diferente daquelas baseadas na linearidade da comunicação escrita alfabética, embora herde em maior ou menor grau suas características verbais. Essa radicalidade do outro-surdo nos é imposta na materialidade comunicacional que envolve a línguas de sinais, língua esta que é mobilizada por um corpo sinalizante que se põe diante de lentes e luzes que o registram.

A teorização flusseriana, como inspiração para um percurso criativo, nos guiou em atividades de exercício de experimentação, formas de proposições de futuro. Nos voltamos às materialidades da comunicação e seu elo de ligação entre suportes (objetos), práticas e mediações, presentes nos vínculos e na comunicação de surdos e não-surdos.

\subsection{A centralidade do vídeo na produção visual surda}

A produção visual dos surdos vem atrelada às suas reivindicações e luta por direitos, sendo central nesta pauta a Educação Bilíngue de surdos. Ela é melhor identificada quando se delineia uma prática comunicacional-tecnológica, pedagógica e cultural. Esta é a ideia de Perlin e Miranda (2003) quando apontam que esta produção dos surdos é fruto de uma experiência visual.

Para estes pesquisadores, a experiência visual surge do que denominam de cultura surda, que é representada pela língua de sinais, pelo modo diferente de ser, de se expressar, de conhecer o mundo, de entrar nas artes, no conhecimento científico e acadêmico, comportando também a necessidade do tradutor-intérprete e de tecnologia de registro e leitura.

As pesquisas de Karnopp, Klein e Lunardi-Lazzarin (2011), Taveira e Rosado (2013) Taveira (2014), nos situam em um tempo em que surdos ditam novas formas e usos de extensões ópticas e corporais: filmadoras, data shows, cenários e didáticas antes não vivenciadas. No âmbito pedagógico também estão inseridas as normas de tradução para língua de sinais em ambientes virtuais e presenciais de ensino-aprendizagem, usando linguagem cinematográfica ou fílmica (vídeo), que estão presentes em Stone (2009), Souza (2010, 2012), Castro (2012) e Campello e Castro (2013). 
O nosso interesse é a comunidade surda e os seus usos coletivos das mídias ópticas digitais, - as telas, as lentes e a luz -, focando na forma como produzem condições novas de registro acadêmico no Ensino Superior, permitindo o enfrentamento de limitações típicas do vídeo, tais como revisões, correções e acréscimos em suas próprias mensagens. Dito isto, quais são as abordagens que iremos defender neste artigo?

Primeiramente, percebemos a necessidade, na comunidade surda, de novas formas de organização de seus discursos, uma produção diferenciada em relação aos artefatos já consagrados em língua portuguesa (LP) escrita, tais como livros e trabalhos de conclusão de curso (TCC) dispostos em bibliotecas físicas ou on-line; diante desta necessidade, buscamos contribuir, junto a esta comunidade, com a formulação de normatizações específicas e adequadas ao armazenamento de suas criações midiáticas em vídeos em Libras.

Acreditamos que os vídeos de monografias em Libras são produtos semióticos que exercem funções similares à linguagem verbal escrita e falada (texto e oralidade) dos ouvintes, produzindo consequentemente formas de leitura próximas ao que Santaella (2004) denominou contemplativa (concentrada, focada e atenta), típica dos textos impressos. São produtos criados na atuação da comunidade surda (surdos e não-surdos) diante de câmeras que substituem o uso da escrita linear como centro da comunicação.

Fomos então em busca da compreensão das formas de registro emergentes para o autor/leitor de língua de sinais, através de imagens e vídeos que, tradicionalmente, não são expressões lineares do pensamento, uma contradição inicial com o formato linear de divulgação científica e acadêmica. A escrita alfabética perde seu espaço, pois existem poucas margens para notações pessoais quando nos deparamos com um vídeo. Optamos, na produção destas monografias, pelo caminho das mesclas de textos não-lineares com os tradicionalmente lineares.

Para isso, foi preciso pensarmos nos sujeitos-autores surdos e não-surdos, que são também atores diante das câmeras, que as usam para suas notações diárias em vídeos em língua de sinais e, para tal, analisamos o processo de construção de seis monografias em Libras; as primeiras defendidas em faculdade de Pedagogia de um instituto de referência na educação de surdos, no quadriênio 2015-2018. 


\section{Formato de investigação}

O formato de investigação assumido nessa pesquisa é o coprodutivo, em que a pesquisa é realizada ao mesmo tempo que se apresentam demandas práticas, neste caso as da comunidade surda formada por alunos do Curso Bilíngue de Pedagogia do Instituto Nacional de Educação de Surdos (INES).

A coprodução, ou mais formalmente a abordagem da pesquisa-ação (THIOLLENT, 2011), inclui momentos de formação dos participantes do Grupo de Pesquisa "Educação, mídias e comunidade surda"4, em que alunos de graduação e pósgraduação, professores do ensino básico e superior e tradutores-intérpretes (TILSP) participam como pesquisadores.

De acordo com as demandas surgidas e sistematizadas como pesquisa, são feitas oficinas complementares envolvendo conceitos e técnicas de comunicação, design e produção visual, conhecimentos estes partilhados por alguns dos participantes mais experientes nestas áreas no grupo, que inclui, além de pedagogos e formandos em Pedagogia, comunicólogos e linguistas. Construímos esta coprodução através de trocas entre os pares e suas necessidades de resolverem problemas durante a consecução de tarefas, sendo que destacaremos aqui o processo de produção de monografias em Libras com alunos do Departamento de Ensino Superior (DESU) do INES.

Decorrente de tais ações, os produtos e métodos gerados pelos participantes são coletados e organizados pelos pesquisadores e alunos. Durante a realização desta pesquisa, a presença do intérprete de Libras $^{5}$, não-surdo ou surdo, juntamente ao orientador de monografia em Libras, visa tanto atuar no acesso ao conteúdo de textos, quanto em mapear a elaboração de glosas escritas e o processo de interpretação-tradução.

\footnotetext{
${ }^{4}$ Grupo de Pesquisa "Educação, mídias e comunidade surda", certificado pela CAPES, iniciado em junho de 2015 no Departamento de Educação (DESU) do Instituto Nacional de Educação de Surdos (INES), sob a liderança dos Professores Adjuntos, Cristiane Correia Taveira e Luiz Alexandre da Silva Rosado, com período de execução de projeto (3 anos): agosto de 2015 a agosto de 2018. A proposta de investigação possui três eixos: a educação bilíngue de pessoas surdas (Libras/Língua Portuguesa); o uso de mídias analógicas e digitais em ações didático-pedagógicas envolvendo a tríade aluno-professor-intérprete de língua de sinais; e como essas ações e seus produtos auxiliam no letramento visual dos alunos surdos. Site do GP: https://edumidiascomunidadesurda.wordpress.com

${ }^{5} \mathrm{O}$ profissional Tradutor-Intérprete de Libras tem como uma das atribuições intermediar / mediar pessoas surdas e não-surdas. Sendo assim, um canal de comunicação através da Libras para a língua oral e viceversa, tendo então: Versão voz na qual a língua fonte será a Língua de sinais versada para a língua alvo, o Português oral; Versão Língua de Sinais na qual a língua fonte será o Português (oral e/ou escrito) e a alvo será a Libras. As atribuições dos Tradutores-Intérpretes da Língua de Sinais (TILS) estão definidas no Artigo $6^{\circ}$ da Lei $\mathrm{n}^{\circ} 12.319$, de $1^{\circ}$ de setembro de 2010, já a Libras foi reconhecida na Lei 10.436 , de 24 de abril de 2002 e regulamentada no Decreto $N^{\circ}$ 5.626, de 22 de dezembro de 2005.
} 
Este trabalho valeu-se dos procedimentos de roteirização, produção de vídeo-rascunho, administração do tempo para executar as monografias como também da edição de vídeos.

Estas etapas mencionadas e as soluções encontradas no trajeto da pesquisa serão objeto de detalhamento neste artigo.

\section{0 que significa ser letrado academicamente para o surdo?}

Para concebermos o que significa ser letrado para o sujeito surdo, precisamos elencar alguns pontos importantes, sintetizados em quatro chaves de leitura usadas neste artigo.

Em primeiro lugar, em relação ao papel representado pelo sujeito, o artífice visual, o ator e o professor são colagens justapostas, necessárias na didática específica do usuário da língua de sinais. Poderíamos dizer que existe uma didática surda com o ingresso no conhecimento científico pelo pesquisador surdo e não-surdo participantes da comunidade surda. Podemos pensar que os suportes e modalidades de comunicação que ainda não possuem tanto relevo na escola, na faculdade e universidade, tais como o cinema, a fotografia, a informática, o uso da visualidade, direcionam o fazer científico e acadêmico voltado à surdez para outras vias, suportes e cenários.

Em segundo lugar, em relação a língua e a expressão visual, no momento em que o português perde seu aspecto central, ganham terreno: o corpo, a oralidade, a sinalidade e o visual. Volta-se ao referente - ao objeto -, à situação propriamente dita. Porém, isso não significa abrir mão do território simbólico, de teorizações densas quando se entra em cena com a comunicação visual junto à língua de sinais.

Em terceiro lugar, a consciência da substância visual pelos que veem não é algo inato. Há o ambiente artístico, cultural, pedagógico e científico a serem considerados como construção social. É preciso o desenvolvimento da acuidade visual e do potencial expressivo, o qual atribuímos, por aproximação teórica, o caso da performance surda no processo de tradução-interpretação e reinterpretação. Mas esse fenômeno, ou melhor, a metodologia e o campo teórico que alicerçam tal performance é palpável e é fruto de experiência empírica a partir de uma comunidade científica e teórica que será destacada neste artigo.

Em quarto lugar, alguns dos professores surdos dominam ou possuem percepções-intuições (feeling) sobre os usos do letramento ou alfabetismo visual e o fazem por meio de trocas de experiência com pares, professores não-surdos ou surdos, 
em incursões experimentais das práticas pedagógicas voltadas à surdez. No entanto, precisamos de clareza quanto às instrumentações práticas para se obter uma formação que proceda discussões e orientações sobre o que seja, de fato, instrumentalizá-los e dar autonomia criativa, com responsabilidade intelectual/autoral, de suas produções acadêmicas em vídeo.

\subsection{Matrizes de linguagem e letramento visual}

Nos importa, com maior intensidade, abrir mão da disputa entre línguas (Libras versus Língua Portuguesa) e observar o comportamento destas na constituição dos suportes e de recursos referentes aos encadeamentos e às misturas entre imagem e texto, entre matrizes de linguagem (sonora, visual e verbal) ${ }^{6}$. O pouco entendimento sobre o que são as matrizes de linguagem e pensamento, principalmente quanto ao aspecto visual e às mesclas entre as matrizes, nos impulsionou ao estudo e à construção de outros olhares relativos ao letramento, à leitura, à escrita e à produção literária e científica em Libras.

Dondis (2007, p. 231) afirma que "só os visualmente sofisticados podem elevarse acima dos modismos e fazer os próprios juízos de valor sobre o que consideram apropriado e esteticamente agradável”. Tal afirmação nos deixa preocupados pela pouca vivência estética, em arte em geral e em práticas específicas como design gráfico e edição de vídeos, encontrada em faculdades, universidades e no público adulto a que nos dedicamos em nosso Curso de Pedagogia no DESU/INES. Dondis recomenda que o alfabetismo visual deve ser uma preocupação prática do educador, uma vez que "as decisões visuais dominam grande parte das coisas que examinamos e identificamos, inclusive na leitura" (2007, p. 231).

Na concepção de Santaella (2012), ler imagens por meio de outras imagens e, talvez, explicá-las por meio de substituições por outras imagens, em links, seria mais próximo da criação artística, muito mais do que constituir-se uma atividade didática (o “como fazer", o "para que fazer" e "por que fazer") do letramento visual. Essa concepção mais artística restaura - ou "combina com" - o que resgatamos da pesquisadora surda Strobel (2008, p. 66): “o artista surdo cria a arte para que o mundo saiba o que pensa, para explorar novas formas de 'olhar' e interpretar a cultura surda".

\footnotetext{
${ }^{6}$ Para a concepção de matrizes de linguagem, ver Santaella (2005).
} 
Optar por mesclas de textos não-lineares com os lineares seria um caminho a partilharmos na produção argumentativa de alunos surdos e não-surdos sinalizantes. A partir desse ponto já faremos uso de exemplos práticos ocorridos desde o momento que o aluno graduando ou pós-graduando começam a esboçar uma conceituação.

Uma orientanda surda, do DESU, ao se deparar com textos em português sobre a condição do surdo diante de barreiras de comunicação, nos mostrou a tela de Susan Dupor intitulada "Family dog", presente na Figura 1, e por ela passeou com os olhos (leitura não-linear) propondo correlações que respaldassem seus argumentos, em Libras (linear), com um detalhe correspondente à obra; um movimento mais adequado que a fez saltar conceitualmente, do que apenas se referindo a um artigo em português. A indagação de que uma imagem que pode ser lida como argumento (MATEUS, 2016) nos leva a pesquisar que a reflexão e o pensamento são possíveis a partir de memórias imagéticas a serviço do suporte em vídeo - e vice-versa.

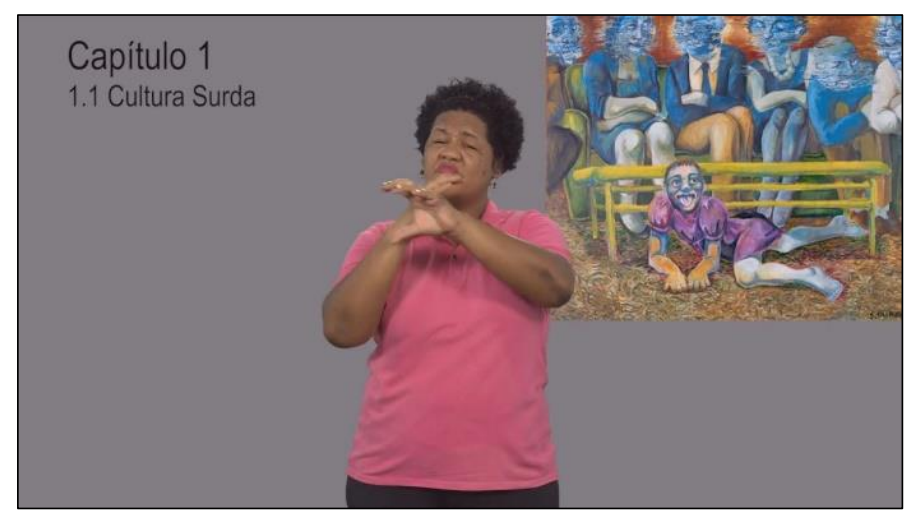

Figura 1: Arte Surda Family dog, de Susan Dupor, e a utilização no processo argumentativo da aluna do DESU em seu Capítulo 1

Fonte: Arquivo da pesquisa

Este ponto nos interroga sobre a qualidade de sujeitos para lidar com este material/arte, cenário e atuações de que se trata a dinâmica de produção da monografia em Libras, desde a produção argumentativa, e é isso o que discutiremos.

\subsection{As diferenças e entrecruzamentos de língua-fonte e língua-alvo na formação bilíngue}

Os textos presentes em artigos, dissertações, teses e livros estão, em sua maioria, em Língua Portuguesa, pois esta é a língua-fonte dos materiais científicos publicados nacionalmente. Este fato faz do aluno surdo e não-surdo um intérprete-tradutor ou usuário de duas línguas, Língua Brasileira de Sinais (Libras) e Língua Portuguesa, ou seja, um 
sujeito bilíngue, ao longo de todo o processo denominado de Educação Bilíngue no âmbito do Curso Bilíngue de Pedagogia no DESU-INES.

O aluno se habitua a defender os seus pontos de vista por meio de argumentação acadêmica, ou seja, saindo do senso comum e se apoiando em teóricos, nos exemplos de empiria, como observação de campo de estágio ou de trabalho, tentando manter-se no debate com consistência teórico-prática através da língua de sinais, sua língua-alvo e que se sente mais confortável e desafiado para a produção de materiais à comunidade surda.

Ao fazer este exercício argumentativo, faz jus ter a opção de finalizar o curso com a apresentação de monografia em Libras, conforme conquista da comunidade surda do DESU-INES ${ }^{7}$. Das dez monografias em Libras produzidas em nosso Departamento, três delas foram produzidas por não-surdos envolvidos com a comunidade surda: uma filha de pais surdos e outros dois alunos que atuam como intérpretes de Libras.

Há tensões entre língua-fonte dos textos científicos e a Libras como língua-alvo, o público a quem ela se destina e aqueles que possuem o poder institucional de propiciar a produção e a estocagem desse material, nos permitindo definir algumas categorias principais da rotina de orientação e produção de monografias em Libras que serão brevemente arguidas durante este artigo, sem a presunção de esgotá-los, mas dando a ideia do percurso realizado.

\subsubsection{As glosas escritas ou glosas intralinguais}

A glosa escrita (SOUZA, 2010) consiste em uma interlíngua escrita em português a partir do texto em Libras. São, inicialmente, em um português aproximado do modo de escrita da língua de sinais, com substituições de termos que possuem maior valor semântico - e gramatical - para a língua alvo.

A glosa intralingual (CASTRO, 2012) utilizada também para transcrição dos aspectos gramaticais de textos da Libras (FELIPE, 1988), ou visando realizar a interpretação-tradução propriamente dita de um texto. É o mesmo que a glosa escrita, aproximando-o da estruturação de pensamento e linguagem dos surdos, ou seja, tornandoa mais próxima da modalidade viso-gestual, viso-espacial e verbal da língua de sinais. A seguir, um exemplo de primeira glosa escrita produzida no processo de argumentação:

Minha pesquisa diz o que?

Não só estimular alunos surdos. Precisa mais

\footnotetext{
${ }^{7}$ Conquista da comunidade surda do DESU-INES liderada (em ordem alfabética) por Luís Mauro dos Santos, Patrícia Luiza Rezende, Valdo Nóbrega, Ulrich Palhares e outros reivindicantes e debatedores deste Departamento de Ensino Superior.
} 
AUTOR, ano 2014, pesquisa mostra dá ler, entender imagem unir imagem. Ouvinte consegue palavra unir palavra unir, igual surdo sinal unir sinal unir. Então, imagem consegue unir imagem, dentro pensamento.

Precisa o que? Perceber experiências vida também entender aluno surdo ter experiência visual. Como?

Elas, crianças, captam, também compreendem mundo visual, também substituição imagem, imagem também a língua de sinais.

Depois a língua de sinais ajuda compreensão da L 2, a escrita do português.

Ela, língua-libras mesmo-nível língua portuguesa.

Eu explico primeiro o que?

Imagem é importante. Eu quero ajudar força-ideia, também defender precisa filmar histórias feitas por-elas, crianças surdas. Tipos vários percepção diferente.

Precisa desenvolver inteligência visual, aprender usar visual.

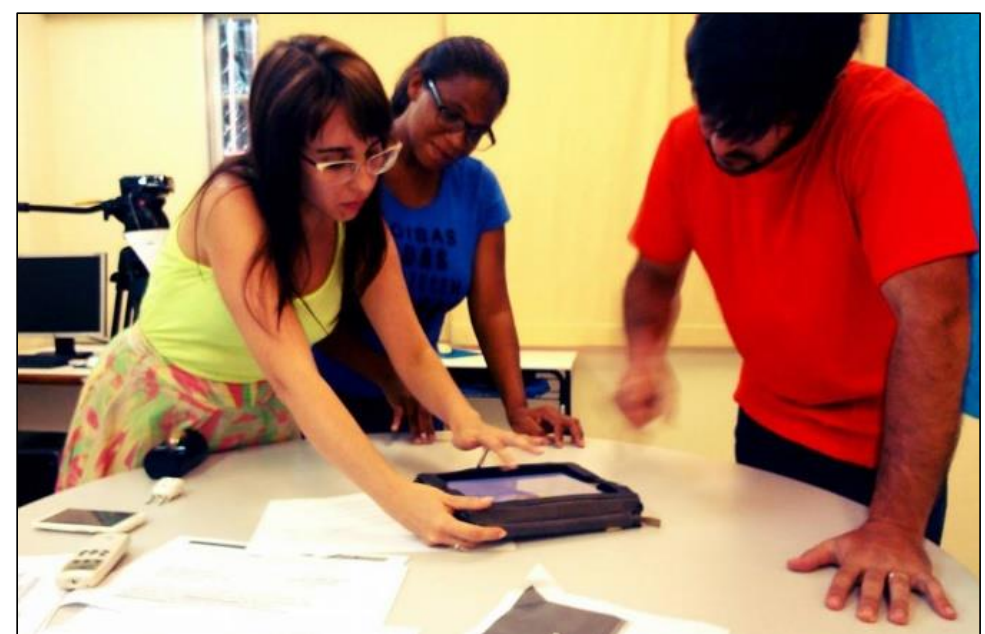

Figura 2: Glosa escrita debatida em tablet no processo de argumentação do aluno do DESU; aluno e professora a direita e a esquerda (pontas) discutem as glosas e a intérprete, no centro da foto, participa do debate

Fonte: Arquivo da pesquisa

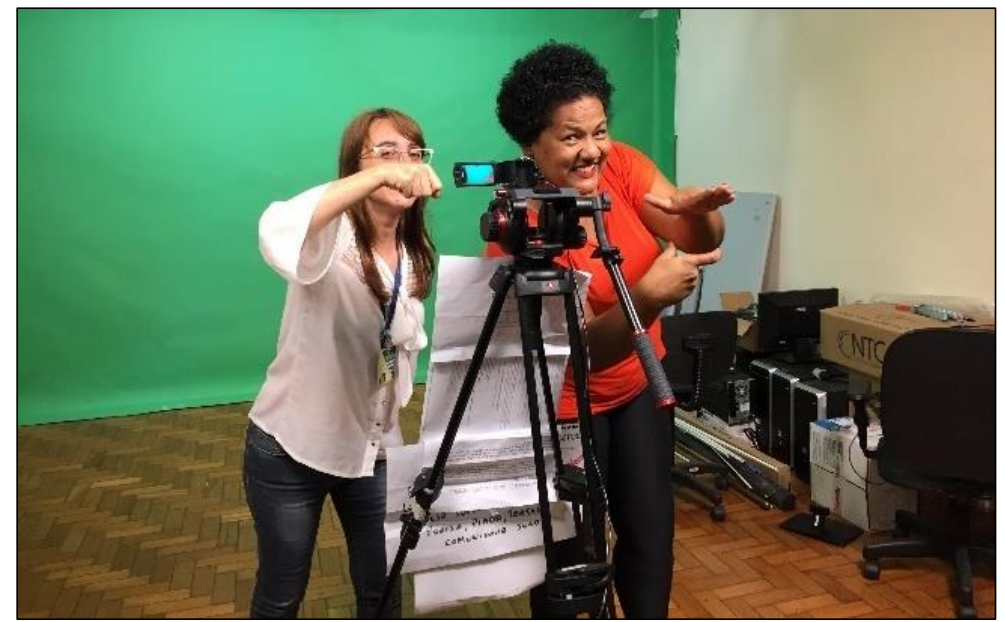

Figura 3: Piada com a Glosa escrita produzida em papel no processo de argumentação do aluno do DESU; aluna faz o sinal de monografia em Libras e a orientadora imita uma manivela Fonte: Arquivo pessoal

Há conflitos diante do grau de informalidade, dos usos coloquiais da língua de sinais, em comparação com a norma-padrão que é utilizada habitualmente por professores 
mestres e doutores surdos, também empregada por parte dos intérpretes da língua de sinais. Felipe (2012) nos alerta sobre o fator de incipiência na escolarização dos surdos tanto em sua língua patrimonial quanto em outras línguas, pois pontua que:

\begin{abstract}
É possível constatar que os surdos que, assumindo uma identidade cultural surda e optaram por utilizar a Libras como língua preferencial, não têm um conhecimento linguístico consciente de sua língua patrimonial e, por isso, a maioria tem apenas uma competência comunicativa de sua própria língua; o que dificulta o desenvolvimento dessa língua enquanto língua de instrução que necessita de uma competência linguística escolar (FELIPE, 2012, p.9).
\end{abstract}

Apesar de haver o risco da não aferição da competência da pessoa surda quanto à língua de instrução, discutimos a revisão realizada por Baker (2006), sem nos atermos à busca do original, da genealogia dos conceitos observados em todas as nuances sobre bilinguismo. Cremos que, sem diminuir a importância da imersão nesses conceitos, estes se referem a uma das etapas dessa pesquisa. O que se verificou no campo foram dados que suscitaram uma ampliação do entendimento sobre o que seria ser letrado - não só verbal, mas visualmente.

Mesmo situando o bilinguismo em termos conceituais, pensando na definição de contornos para que não criemos um surdo bilíngue idealizado que não corresponda aos estudos de longas décadas sobre bilinguismo, a ideia de letramento visual, em termos de práticas de orientação quanto à monografia em Libras, adquiriu simultaneidade à própria ideia do bilinguismo. Dito isto, pensamos que esta prática de orientação monográfica pode alavancar ambas as línguas que ainda se encontram em processo de aprendizagem e aprimoramento para o surdo e o não-surdo, assim como se dá com qualquer sujeito bilíngue, e, ainda, que as próprias linguagens que envolvem a visualidade, tais como a cinematográfica (filmagem) corroborem a ideia de letramento visual.

\title{
3.2.2 As glosas no contexto de letramento
}

As glosas conferem suporte ao procedimento de tradução-interpretação em vídeo, podendo ser utilizadas como primeiras notações em forma de slides em PowerPoint (ou software equivalente). As ferramentas criadoras de apresentações são comumente usadas pelos surdos para este fim, assim como em trabalhos de tradução (OLIVEIRA; SILVA, 2014), exibindo textos no monitor de computador da sala em que estiverem sendo construídas as orientações para monografia. $\mathrm{O}$ aspecto diferente encontrado no decorrer de nossa pesquisa é que: 
- A glosa é exterioridade fundamental do pensamento para a roteirização durante todo o processo de tradução e enriquecimento dos textos da língua-fonte para a língua-alvo.

- O rascunho em vídeo precisa ser filmado nas discussões de orientação desde o primeiro momento e a cada encontro entre orientando e orientador.

Deste modo, o aluno graduando ou pós-graduando pode, juntamente com a equipe de professores e intérpretes, exercitar a saída do uso coloquial da língua para um modo argumentativo, formal, dentro da estrutura científica que prima por basear-se em autores e na demonstração de seus conceitos-chave, dentro de uma norma culta de exposição. Em síntese, as glosas se constituem ferramenta importante diante da necessidade de roteirização de vídeo pré-defesa ou o que chamamos de filmagem-rascunho.

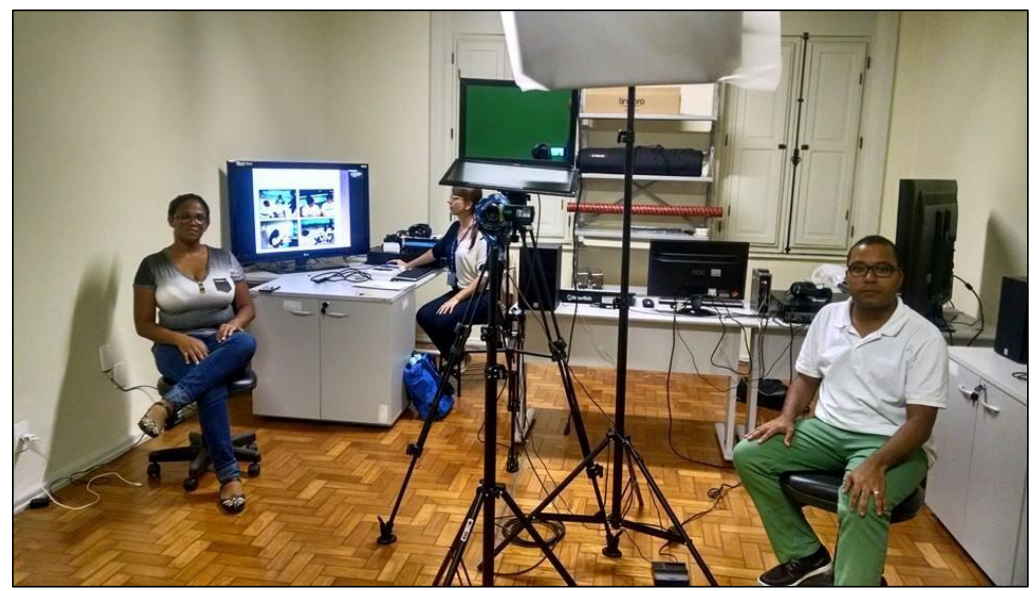

Figura 4: Vídeo-rascunho filmado no processo de orientação do aluno do DESU Fonte: Arquivo da pesquisa

\subsection{A filmagem-rascunho}

A filmagem-rascunho da monografia em Libras se faz necessária à medida que o professor orientador realiza perguntas sobre o tema ou projeto de pesquisa, provocando argumentações academicamente estruturadas, mostrando teorias e autores que combinam com o tema apontado. As respostas e o exercício argumentativo, em Libras, já explicado anteriormente como necessário à produção de glosas, são o primeiro ato ou performance surda de reelaboração das teorias apreendidas ao longo do curso de graduação, passandoas da língua-fonte, português escrito, para a forma argumentativa na língua-alvo, a Libras.

Pelo que vivenciamos no período de três anos que desenvolvemos parte desta pesquisa dentro do DESU-INES (2015-2018), o apropriado seria o aluno graduando ter o costume de gravar, em vídeo, os seus resumos de artigos lidos; ou fazer registros em 
glosa, com anotações referentes ao esforço esquemático de traduzir e retraduzir da língua mais confortável, na maioria das vezes a Libras, para o registro em português e viceversa, em influência mútua das línguas.

Em suma, o mais interessante é o processo pelo qual a pessoa se torna bilíngue, enquanto sujeito aprendiz de duas línguas, pois é um processo de aprendizagem que irá variar em seu alcance, complexidade, grau de habilidade e domínio ao longo dos anos de aquisição da primeira e segunda línguas (MAHER, 2012).

$\mathrm{O}$ assunto que desperta a atenção do graduando surdo, e que the rende o aprofundamento teórico durante a consecução da monografia, nem sempre sofre elaboração crítica, até mesmo pelo acesso dificultoso da língua-fonte, no português escrito. Uma das hipóteses seria de que este aluno faz a maioria das suas apreensões a partir das aulas expositivas de seus professores, nas disciplinas cursadas, e da leitura simplificada de textos previamente sublinhados, destacados, com ênfase no estudo dos slides de aula.

Portanto, em sua formação, muitas vezes parte-se de um acesso empobrecido à Língua Portuguesa, com a simplificação da escrita do português para surdos, inclusive em ambiente universitário. Posteriormente, este círculo vicioso acaba por desvalorizar a capacidade produtora de textos em Libras, recomeçando a circularidade de um procedimento iniciado com a baixa expectativa em relação ao aluno e pesquisador. Incorremos todos, ainda, em maior ou menor grau, neste erro, por entendermos que lacunas de escolarização deste aluno devam ser corrigidas.

\subsubsection{O que são glossinais?}

Os glosinais ou glossinais (STONE, 2009; SOUZA, 2010; CAMPELLO; CASTRO, 2013) são sinalizações visualizadas em Libras e que são utilizadas para elucidar um trecho ou um conceito. Entendemos, mesmo que nos arriscando na afirmativa sobre o termo, que estas são um aprimoramento da técnica de escrita em glosas no âmbito da tradução e interpretação de línguas de sinais.

Esse movimento ocorre, sistematicamente, no intuito de sofisticar as performances de tradução-interpretação, já que saímos de uma modalidade oral-auditiva para uma modalidade viso-gestual/viso-espacial. 


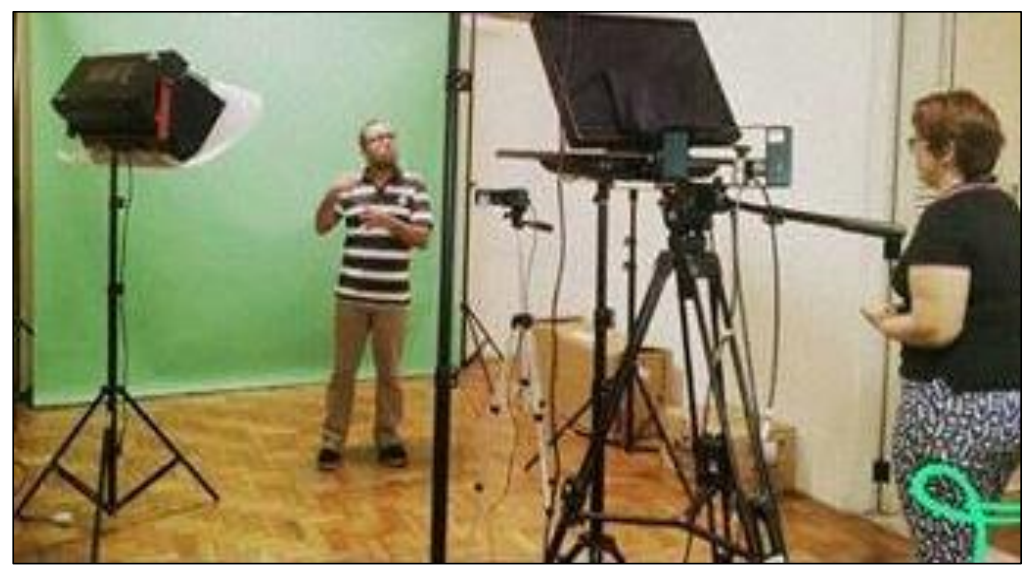

Figura 5: Intérprete de Libras reinterpretando um trecho visando aclarar o processo de orientação do aluno do DESU

Fonte: Arquivo da pesquisa

Esta performance de tradução-interpretação pode ser realizada por surdos e nãosurdos.

O tradutor-intérprete pode se posicionar atrás da câmera filmadora oferecendo o devido suporte ao aluno-orientando, realizando sinalizações em Libras do material escrito em Língua Portuguesa, acrescentando comentários, exemplos, casuísticas que auxiliem o aluno que está realizando e/ou aprimorando a interpretação na língua de sinais - constituindo-se uma performance de tradução-interpretação.

Estas notações também podem ser escritas - indo e voltando do texto-fonte para o texto-alvo, até que o trecho ou conceito atinja notações e reinterpretações na própria Libras. Enfatizamos que estas notações não podem de modo algum se distanciar da teoria que está sendo estudada, ou teve sua origem na língua-fonte (língua portuguesa escrita ou outra), mas que pode ser enriquecida pela língua-alvo, a língua de sinais.

Recentemente, os alunos da graduação do DESU já conseguem encontrar materiais monográficos e artigos em língua de sinais podendo realizar uma citação ou rodapé explicativo em material com a mesma língua-fonte, a Libras. No exemplo a seguir, o trecho de texto de outro trabalho monográfico (quadro menor com fundo amarelo) é colocado diretamente no vídeo sem que fosse necessária uma reelaboração discursiva da autora dessa monografia (autora da monografia atual ocupa a tela com fundo cinza). Notem que não é o mesmo ator, mas um recorte direto de outro pesquisador. 


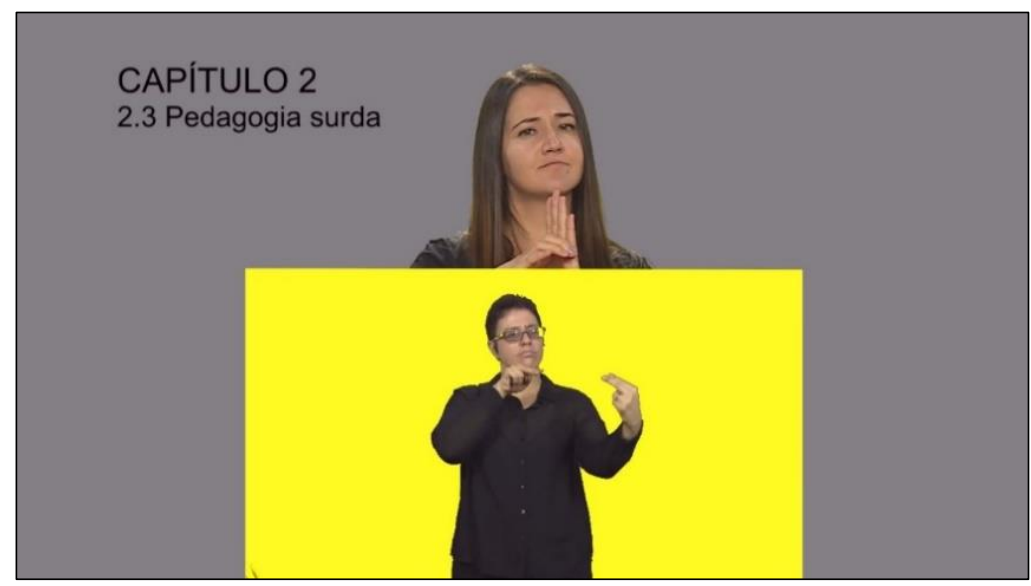

Figura 6: Centralizada na parte inferior da tela, fundo amarelo, trecho em Libras de outra monografia

Fonte: Arquivo pessoal

\section{0 desenvolvimento no DESU-INES de regras próprias para a confecção de monografia em Libras}

\subsection{O ator-tradutor ${ }^{8} \mathrm{e}$ a interpretação/reinterpretação com o uso de roteiro}

Em diversos momentos ao longo da confecção da monografia em Libras, realizase a interpretação-tradução de textos, aproximando-o do que pode ser denominado tradução interlíngua (abordado no tópico sobre glosas e glossinais). No entanto, devemos chamar a atenção para o uso de roteiro. O professor-orientador e os seus alunos orientandos, em estreito acompanhamento dos intérpretes-tradutores não-surdos ou surdos redigem, conjuntamente, um roteiro com especificidades híbridas de conteúdo científico-acadêmico e das particularidades quanto ao suporte midiático (vídeo) - uso de esquemas, fotos, marcações para chamar a atenção quanto ao sinal de batismo do autor, início e término das citações - sempre preservando a autoria do aluno-orientando e sua postura crítico-discursiva.

Em primeiro lugar, percebemos durante esta pesquisa que a ausência de roteiro compromete a sequencialidade e a coerência do conteúdo do texto científico-acadêmico (sua linearidade), além das oportunidades de enriquecimento da língua, com a definição de termos e conceitos-chave. Estamos no momento em que há a necessidade de convencionar sinais e desenvolver discussões conceituais. Este movimento ocorre quando o aluno-orientando está diante de nuances da interpretação de um construto ou de uma

\footnotetext{
${ }^{8}$ Segundo Quadros e Souza (2008, p. 175), “[...], é uma língua vista pelo outro, é uma língua que usa as mãos, o corpo, as expressões faciais, é uma língua que depende da presença material do corpo do 'tradutor', por isso, também 'ator'".
} 
defesa argumentativa baseada em autores que demandam vocabulário científico-teórico apropriado a uma determinada área ou estudo.

No caso de uma monografia em Libras, sutilezas conceituais, como no exemplo destacado a seguir, nos fizeram perceber a necessidade de mostrar que a língua de sinais e a língua portuguesa escrita, quanto ao conceito "letramento verbal", precisavam estar em equilíbrio. No entanto, havendo as características do processo de "letramento visual", que suscitava do aluno-orientando um esforço para elucidação de sinal/sinais, era necessário que o argumento e os conceitos também tivessem uma sinalização clara do ator-tradutor. O aluno, juntamente com o orientador e o intérprete-tradutor, procedeu a seguinte notação inicial:

Letramento Geral [Sinal de Letramento antigo], conceito discutido a partir de Magda Soares

Letramento Verbal [Sinal existente, atual], sinal remetendo a letrar-palavra. Letramento Visual [Sinal faltante, carecendo de enriquecimento] remetendo a letrar-visual, conceito discutido em Donis A. Dondis, Lucia Santaella.

Dentro do que nos sinaliza Stone (2009), a norma surda de tradução opera fora do contexto de saída da língua-fonte, podendo chegar a enriquecê-la, o que ocorreu de fato no produto final após as decisões tomadas, nos deixando ver traços do aluno-orientando, de sua performance, enquanto sinalizava em sua ação de ator-tradutor.

No intuito de adensar as performances de tradução-interpretação e as argumentações do próprio autor da monografia, filmadas em Libras durante o período da orientação, esquemas como este, contendo discussões conceituais e sinais faltantes, nos têm auxiliado. Esta primeira aproximação esquemática prepara o conteúdo e os conceitos de modo que:

- Orientador-professor discute com o orientando-aluno o que está no material em glosa escrita ou glossinais, visando ampliá-lo na execução da filmagemrascunho em Libras.

- Orientando-aluno discute com o intérprete-tradutor e com o orientadorprofessor sobre a aproximação ou não da sua reinterpretação na língua de sinais - na língua-alvo - e o referencial teórico em outras línguas-fonte, ou seja, nos conteúdos de artigos, dissertações e teses redigidos em Português escrito (ou outras línguas).

- Orientando-aluno discute com a equipe de tradução e validadores externos 
(professores doutores surdos, GT Manuário ${ }^{9}$ DESU-INES) sobre a pertinência da criação e definição de novos sinais.

Os intérpretes-tradutores surdos e não-surdos que compõe a equipe debatem também sobre outras estruturas gramaticais. Um dos participantes da pesquisa, tradutorintérprete, comenta:

Neste momento em que se escreve - e se registra em vídeo - o que se pensa, em Libras, conseguimos ajustar o ator-tradutor surdo a respeito da necessidade de apresentar em seu discurso tradutório os pronomes pessoais (eu, tu, ele, eles) e demonstrativos e também, a necessidade de apresentar os advérbios de tempo, intensidade e lugar (aqui, ali, lá).

Este aspecto salientado pela equipe copartícipe desta pesquisa robustece a ideia de que o aluno-orientando também demanda ser ator (ator-surdo ou ator não-surdo bilíngue) para atuar diante das câmeras e dizer o seu discurso de acordo com o gênero acadêmico e monográfico. Durante a performance tradutória e de interpretação e reinterpretação de seu próprio discurso, e nas citações de outros discursos, precisa sinalizar a expressão facial e corporal que corresponda exatamente ao sentido. Exemplos são as expressões de perguntas ou questões de estudo, as afirmações ou críticas que contrastam ideias e até mesmo a neutralidade de expressões em outras partes do corpo do texto, não sendo somente atributo de uma gramática da língua de sinais, mas também da própria estrutura da monografia em vídeo, garantindo a compreensão do seu texto (em vídeo) por leitores.

Outro aspecto a ser destacado pela equipe é a importância de trabalhar o tempocronologia no relato verbal, em vídeo. Observamos que o aluno-orientando ao fazer a sua narrativa argumentativa, em Libras, precisa de direção de vídeo, que pode ser o par orientador proficiente em Libras e/ou o intérprete, pois, ainda assim, incide em equívocos quanto a sinalizar: o tempo remoto, relatando sobre o passado, o tempo presente e os dados coletados na atualidade, ou, ainda, as perspectivas futuras, algo esperado ou pretendido a partir do estudo e apresentadas na conclusão.

Estes aspectos são apenas exemplos do que ocorre na língua de sinais, da passagem para a língua-alvo, no texto monográfico, de modo que a narrativa do sinalizante se torne mais coesa e coerente, apresentando clareza e fluidez para seu leitor (correspondente a um espectador de vídeo). A monografia em Libras tem o rigor

\footnotetext{
${ }^{9}$ Dicionário Terminológico Bilíngue (Libras, Português): Tem como objetivo contribuir para a expansão lexical da Libras por meio de pesquisa, registro, validação e divulgação de sinais existentes e a criação de novos sinais relativos às diferentes áreas curriculares do Curso Bilíngue de Pedagogia do INES. É coordenado pelas professoras Janete Mandelblatt e Wilma Favorito.
} 
científico monográfico, no entanto está sujeita às propriedades de um veículo de difusão que não é o impresso: o vídeo. Com o investimento em dissertações em versão Libras, a opção de consulta e a referência de material em vídeo, na mesma língua-fonte, modificará o cenário que possuímos hoje no DESU-INES.

Para isso, organizar os vídeos-rascunho em pastas no computador para serem levadas ao estúdio de gravação foi uma das etapas mais simples, porém fundamental, pois esses vídeos são usados como guias de gravação (apoio visual), com o texto em Libras a ser visto e reproduzido diante da câmera profissional e estúdio do próprio INES. A compreensão das partes que compõe uma monografia em Libras se faz teor programático relevante aos professores de metodologia científica, o que não significa, como ainda é erroneamente entendido até mesmo no próprio ambiente de Educação de Surdos, uma transposição das normas de monografia em língua portuguesa para a língua de sinais.

\subsection{A criação e definição conceitual dos termos-chave: a importância deste movimento-circulação para o DESU-INES}

O aluno-orientando surdo tem o desafio de definir conceitualmente os termoschave ou as ideias-chave da monografia em Libras, as incluindo posteriormente no glossário terminológico. Como há muitos sinais utilizados no DESU-INES para terminologia específica ainda não registrados em dicionário terminológico, é pertinente fazer uma lista com essa terminologia a ser investigada e discutida. Caso haja termos que estão sendo utilizados para conceitos que ainda não têm sinais, o orientando, juntamente com seu orientador e equipe de trabalho no qual há tradutor-intérprete surdo e não-surdo, poderão apresentá-los à banca de defesa de monografia.

O sinal pouco usual ou criado pelo aluno-orientando, com a devida checagem da equipe de orientação, poderá ser validado futuramente. A validação futura do sinal é realizada por meio da comunidade linguístico-acadêmica a qual se está inserido.

Este movimento de optar por termos em língua de sinais e conceitos principais, definindo-os e deixando-os evidentes em glossário terminológico na abertura da monografia, faz parte do trabalho de conclusão de curso e objetiva o uso mais formal e acadêmico para abordar o tema ou assunto.

Os alunos costumam ficar em dúvida sobre o uso mais formal e acadêmico de diversos termos. Portanto, é preciso consultar os professores surdos mais experientes e 
trabalhar tais conceitos e sinais com a sua equipe de orientação de monografia em Libras. Diante dos primeiros resultados desse trabalho de pesquisa, vislumbra-se um movimento ainda mais forte de incentivo à definição de termos pelos alunos, como forma de impulsionar o desenvolvimento da Libras formal. Este movimento ocorre sob tensões geracionais, hierárquicas e sob olhares intervencionistas, por vezes de intérpretes ou de lideranças não-surdas.

A seguir, na última etapa deste artigo, levantaremos as particularidades de suporte em vídeo.

\subsection{A filmagem oficial em estúdio}

Ao filmar os rascunhos em vídeo e nomear as pastas de organização de capítulos, alocando os vídeos pertencentes a cada capítulo e subcapítulos, o aluno percorre o primeiro passo da organização para a filmagem em estúdio semiprofissional ou profissional. No caso do DESU-INES, se constitui o que chamamos etapa final de (re)gravação, descrita a seguir.

Esta etapa, para ser realizada no DESU-INES, precisou contar com a experiência realizada em universidades que já produziram vídeos científicos em Libras, com regularidade, como ocorre na UFSC. Esta experiência está documentada em pesquisas sobre tradução/encenação na Língua de Sinais e a equipe de tradução que compõe o Curso de Letras-Libras (QUADROS; SOUZA, 2008; OLIVEIRA; SILVA, 2014).

Para viabilizar a gravação no INES, resolvemos proporcionar ao aluno que desenvolve sua monografia em Libras o ambiente de estúdio já existente no Departamento de Desenvolvimento Humano Científico e Tecnológico (DDHCT-INES), assim como a equipe de tradução existente no DESU. Estudamos junto com os profissionais do estúdio a iluminação adequada, o uso correto do fundo (o Chroma Key verde ou azul), o enquadramento ajustado do aluno (plano de filmagem). Procuramos seguir, inicialmente, as regras próprias presentes na primeira versão do Manual de monografia em Libras e Língua Portuguesa do Curso de Pedagogia Bilíngue do DESU-INES (DESU/INES, 2015).

A direção de gravação em estúdio, da filmagem final, pode ficar a cargo do professor-orientador, do intérprete-tradutor e/ou do próprio aluno. Na escrita da claquete, que ajuda a organizar o material filmado feito no estúdio, recomendamos a presença dos seguintes itens/seções da monografia a serem gravados: a. Capa; b. Resumo; c. Glossário; 
d. Introdução; e. Capítulos de Desenvolvimento (1, 2, 3, n); f. Conclusão; g. Outros (Agradecimentos, etc.).

Além das partes básicas, temos levado para o estúdio, de forma organizada, as citações e os rodapés que são filmados de modo que saibamos usá-los no momento da edição final. Para isso existe a tarefa de direção do vídeo, com um elemento da equipe orientando o que será escrito na claquete - número do capítulo, subcapítulo, início de uma citação -, a hora de iniciar e de cortar uma gravação. Os profissionais de estúdio do DDHCT-INES instruem a equipe sobre posição do ator-tradutor, e de regras gerais de filmagem a partir de normas construídas pelo DESU-INES para os trabalhos monográficos.

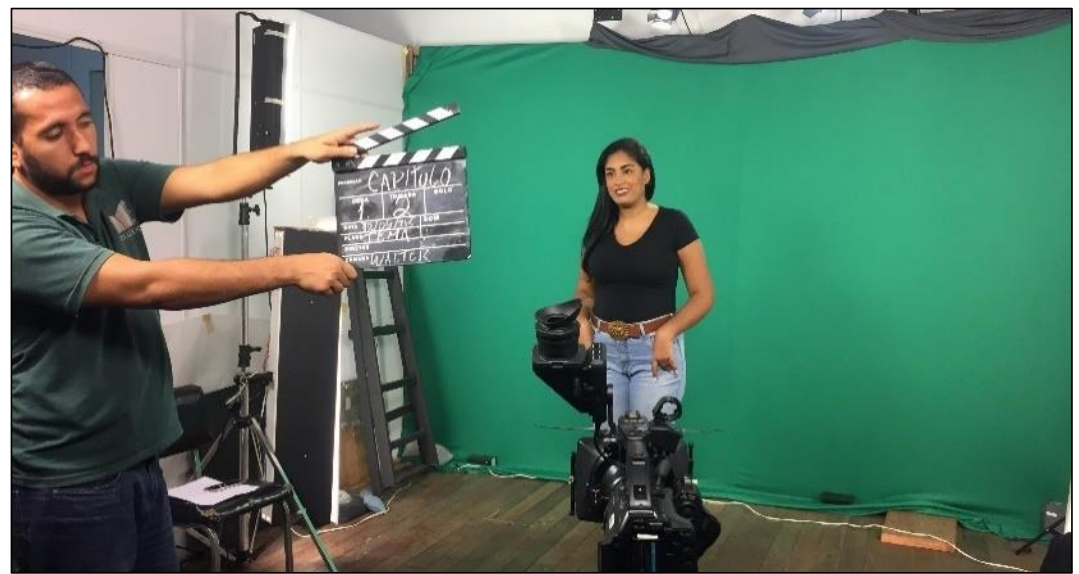

Figura 7: Filmagem oficial no estúdio do DDHCT/INES e o uso da claquete Fonte: Arquivo pessoal

Nesta etapa, o orientando já está com o texto em Libras, com o devido adensamento textual e argumentativo e a interpretação flui com os rigores necessários à uma monografia em Libras. Os rascunhos em vídeo, já em Libras, que foram feitos no DESU-INES, serão usados em substituição ao teleprompter com glossinais, pois já estarão prontos para serem visualizados no ato da interpretação e elaboração do produto final, em estúdio.

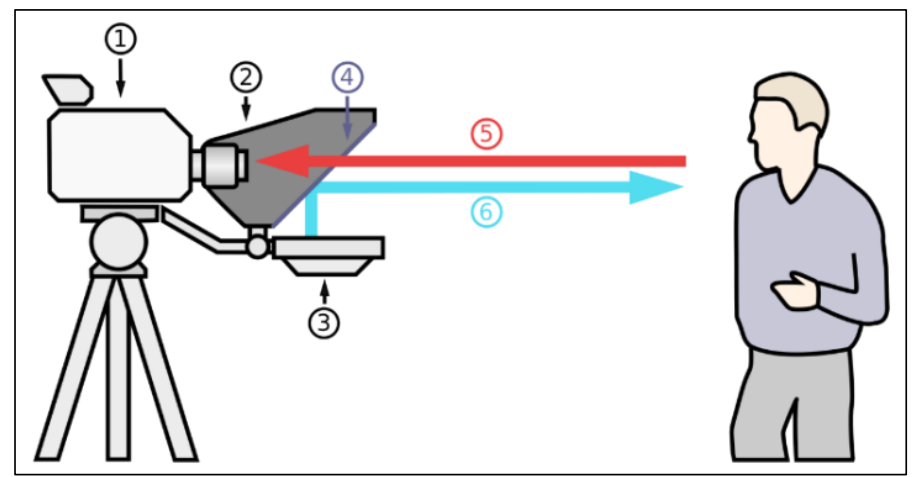




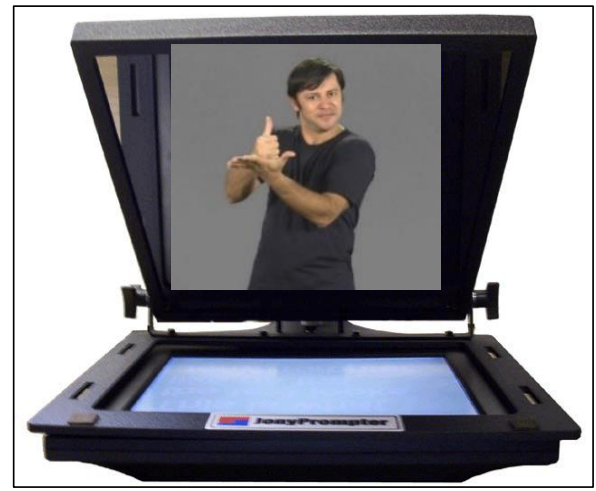

Figura 8: Rascunho em Libras visualizado pelo aluno no estúdio oficial

Fonte: Arquivo pessoal

Vale ressaltar que, em alguns momentos, alunos não-surdos optaram por ouvir as suas glosas gravadas em voz. No entanto, até o momento, os alunos surdos, em sua totalidade, optaram por rever os seus rascunhos em vídeo, abrindo mão de seus textos escritos, anteriormente, em glosas e glosinais.

\subsection{Duas especificidades dos vídeos acadêmicos em língua de sinais: as citações diretas e os rodapés}

O que será citação direta precisará ser sinalizado entre aspas e ter o nome do autor, ano e página da publicação onde foi retirado o trecho, sendo esta uma regra facilmente observada em monografias em Língua Portuguesa. O que será citação indireta precisará de uma explicação e modo de dizer próprio do autor da monografia ou da dissertação, e precisará do nome do autor e ano da obra (tese, livro, artigo) de onde foi retirada a ideia, como já é também conhecido em regras de monografia em português. No entanto, da primeira vez que é citado o nome do autor em Libras, deve-se usar o sinal de batismo ${ }^{10}$, sendo importante usar também a soletração, que chama-se datilologia, ou será necessário ter o autor no glossário de abertura na monografia, com legenda em português (na cor amarela), e das vezes subsequentes, usar apenas o sinal de batismo do autor.

A citação direta é uma citação literal, entre aspas. Mesmo traduzindo-a para outra língua, a Libras, respeita-se o modo original por ser uma definição ou conceituação difícil de dizer de outra forma, já que o autor citado o faz de maneira exemplar e estimada no cenário acadêmico, sendo plausível de se transpor das regras de monografia em Língua Portuguesa. Lembramos que já há implícita uma tradução, no entanto há um recurso visual, e aplicação de estilos, com o uso de cor vermelha, já que o suporte em vídeo nos

\footnotetext{
${ }^{10}$ No glossário de abertura da monografia pode constar a lista dos autores principais que possuem sinal de batismo pela comunidade surda, evitando a datilologia no corpo do vídeo.
} 
proporciona outro formato que, por vezes, chega a atingir o próprio conteúdo, como veremos na situação de rodapés.

Em monografias em Libras feitas no DESU, as citações diretas são inseridas com a tela original pausada, e a descrição em quadro secundário com $30 \%$ da área da tela com fundo vermelho. Conforme já salientado, temos verificado materiais veiculados por universidades e alunos surdos pesquisadores que já apresentaram as suas produções em vídeo, como é o caso de Castro (2012).

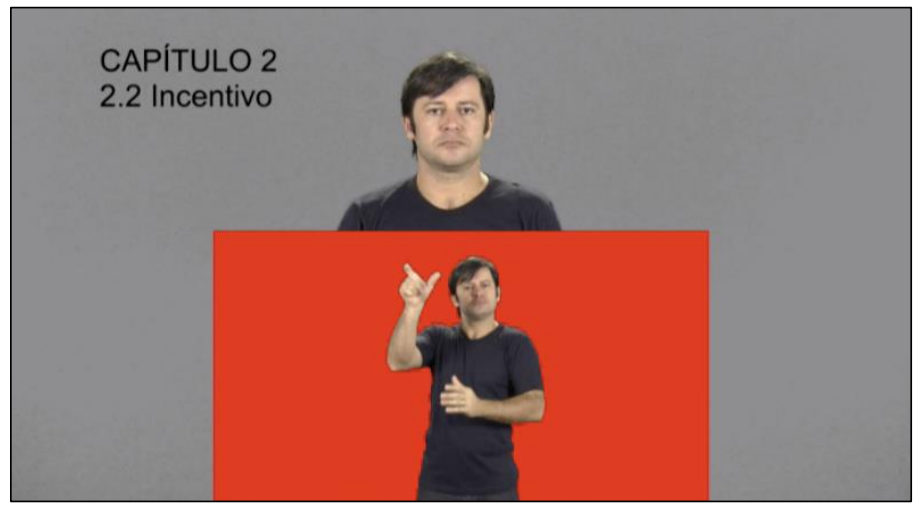

Figura 9: Citação direta com fundo vermelho

Fonte: Arquivo pessoal

Para citação direta de língua-fonte em vídeo - monografia, dissertação ou artigo em Libras - já foi possível conjeturarmos a necessidade de copiar o trecho do vídeo, inserindo-o de acordo com as normas de citação, ou seja, aplicando-se o fundo vermelho.

As notas de rodapé são indicações, observações ou acréscimos feitos ao textovídeo em Libras. Refere-se a uma especificação ou complemento que não está dito, ocorrendo uma pausa em vídeo para dar maior detalhamento a uma expressão ou conceito. Merecerá o rodapé de referência ou explicativo ${ }^{11}$, os conceitos ou expressões que demandam aprofundamento ou apresentação de terminologia em Libras, com a descrição.

Na monografia em Libras do DESU as notas de rodapé são feitas a partir da tela original pausada no sinal referente a conceito ou expressão em língua de sinais novo ou fundamental para a pesquisa. É exibida em quadro secundário com $30 \%$ da área da tela, centralizado na parte inferior da tela, em fundo amarelo.

\footnotetext{
${ }^{11}$ Essas notas podem ser de referência (que indicam fontes consultadas ou remetem a outras obras onde o assunto em questão foi abordado de forma mais aprofundada) ou explicativas (esclarecimentos, comentários que não possam ser incluídos no texto-vídeo).
} 


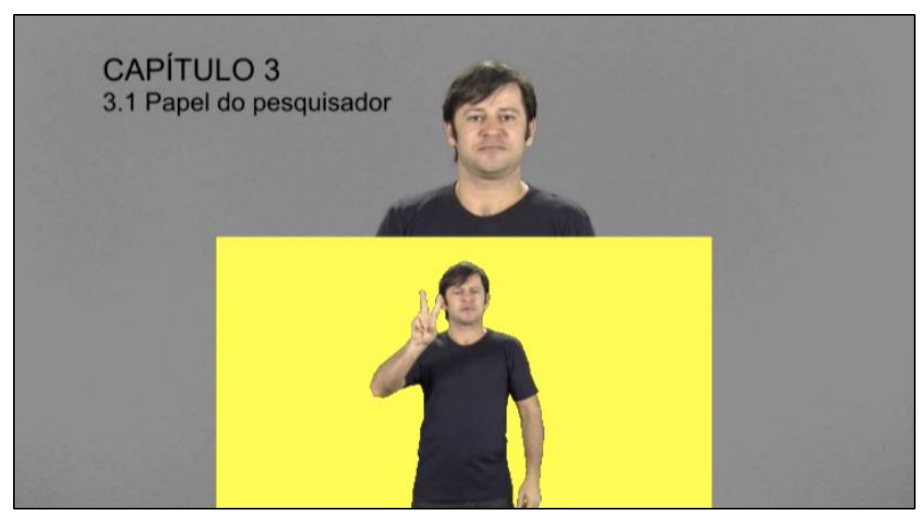

Figura 10: Nota de rodapé, centralizada na parte inferior da tela, fundo amarelo Fonte: arquivo pessoal

Um complicador que tem sido enfrentado e, ainda, sem regra oficializada em nosso manual de monografia (DESU/INES, 2015), é que não é possível fazer citação direta com outra cor de fundo (fundo vermelho) dentro do rodapé (fundo amarelo), pois haveria conflito das opções de cores. No rodapé, se houver necessidade de citar um autor, recorremos, por enquanto, à citação indireta. Deste modo, estamos diante de uma mudança quanto à forma, incidindo no conteúdo sinalizado. Uma possibilidade para resolver esta questão, ainda a ser discutida, seria a aplicação de um contorno (borda) amarela com um fundo vermelho predominante na nota de rodapé durante a citação direta.

Recentemente, nos últimos doze (12) meses dessa pesquisa, já foi necessário inserirmos mais duas cores novas de fundo:

- O azul para discursos em Libras extraídos de entrevista.

- O fundo laranja para destacar uma entrevista em Libras inserida na íntegra.

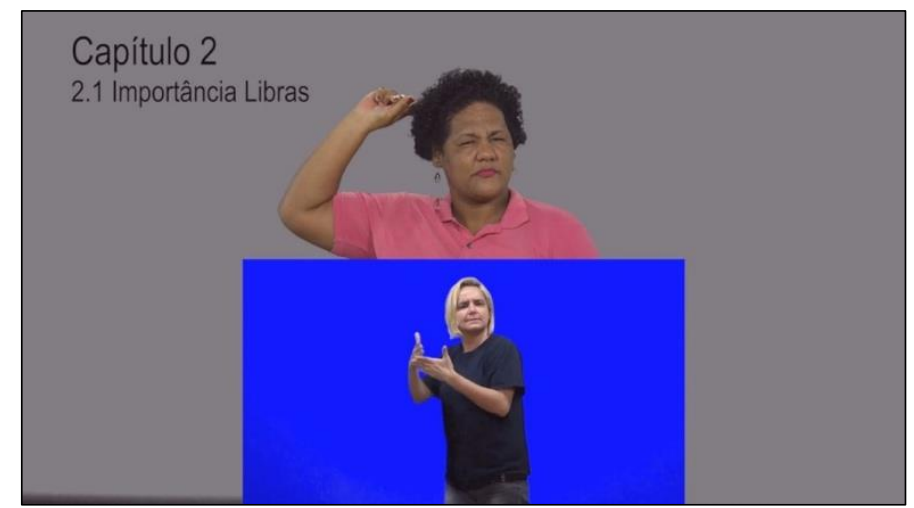

Figura 11: Citação de trecho de entrevista, centralizada na parte inferior da tela, fundo azul Fonte: arquivo pessoal 


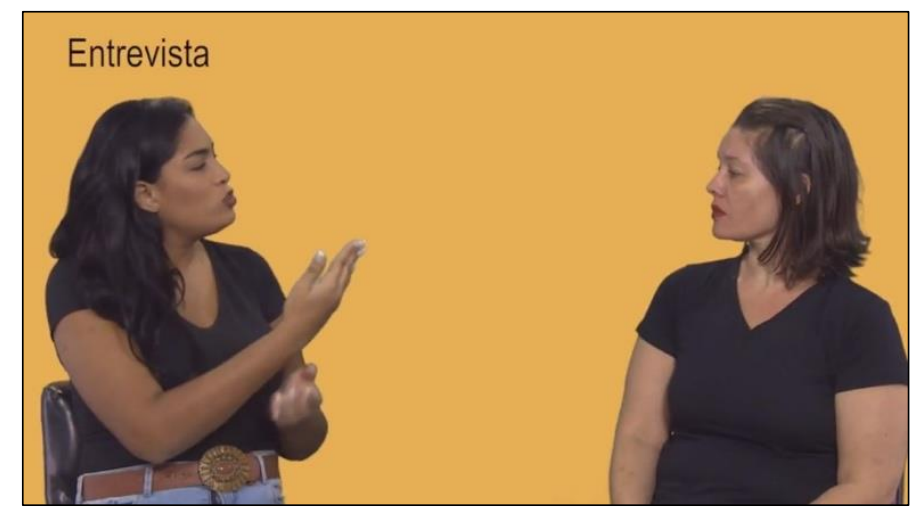

Figura 12: Entrevista na íntegra tomando toda a tela, fundo laranja Fonte: arquivo pessoal

\subsection{Outras questões postas a partir da sistemática da edição de vídeo}

Construir uma forma de redução dos títulos e subcapítulos em língua portuguesa para a edição de vídeo é uma das primeiras situações diferenciadas enfrentadas durante o trabalho de produção de monografia em Libras. Esta situação pode ser tema em oficinas no grupo de pesquisa, quando se estuda a criação de categorias, etiquetagem, agrupamento de temas afins (estudos de taxonomia).

Ao nomear as pastas de organização de capítulos e ao nomear os vídeos de subcapítulos já se pode pensar em um modo resumido em uma, duas ou três palavras. No entanto, alunos e professores possuem dificuldade nesta redução. Estas reduções são necessárias ao se legendar o nome dos capítulos, posicionando-os a esquerda do ator, pois temos que ter cuidado para que não se estendam até a cabeça do mesmo. Por mais singelas que sejam tais observações, nada do que se está dizendo neste artigo é óbvio para o nosso alunado ou equipe de professores e de intérpretes-tradutores.

Imagens e vídeos a serem inseridos devem estar dispostos de forma organizada, em pastas, para que não nos percamos nos elementos que serão introduzidos em vídeo. Devem ser imagens (fotos, desenhos) em boa resolução (150 dpi no mínimo para fotos e resolução de 720p ou 1080p para vídeos), acrescentados de forma criteriosa, de modo que tragam informações complementares ao texto em Libras, ou seja, contribuam com a discussão. Não podem ser mera ilustração sem a devida conexão com o conteúdo em Libras. Este aspecto da complementariedade entre imagem e texto também nos demanda oficinas no grupo de pesquisa que incidem sobre letramento e alfabetismo visual, características e mesclas das matrizes de linguagem verbal, visual e sonora. 
Algumas inovações têm ocorrido a partir de nossos estudos sobre a gramática visual e as formas de introduzir elementos em pós-produção. A seguir, duas capturas de um mesmo trabalho monográfico que quebram a regra usual afirmada no parágrafo anterior. Elas aconteceram em uma monografia em Libras em que o tema era o conto de histórias e decidiu-se brincar com os elementos visuais, tais como personagens e local de produção de materiais didáticos (figura 13), que foram expressivamente alterados para que a atriz (autora) dialogasse e se mostrasse inserida, interagindo com materiais e cenários, apontando e se comunicando com os mesmos.

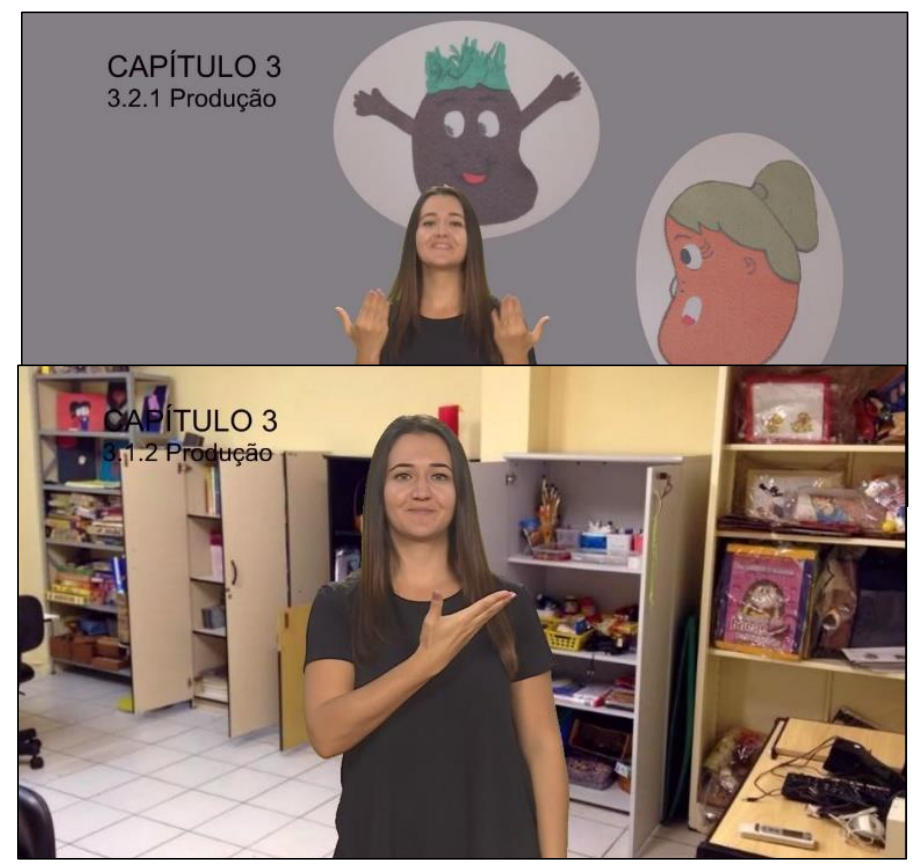

Figuras 13 e 14: Centralizada e menor ou centralizada e maior se insere com personagens e em ambientes para simular a vivência da produção de materiais didáticos para o conto de histórias

Fonte: arquivo pessoal

Objetos ou artefatos oriundos do meio impresso, linearmente concebidos, se beneficiam da leitura pausada, das anotações em suas margens. Quando alteramos para a lógica do vídeo, em suporte DVD, as implicações de uso de um material em movimento, já que a forma de usar é muito diferente do livro e monografia impressos, nos leva a algumas tensões e necessidade de novas convenções, visando aproveitar o enriquecimento da modalidade vídeo, antes não permitido no material impresso.

O vídeo da monografia em Libras tem um tempo máximo convencionado de uma hora e meia de duração. Além disso, nos questionamos sobre como tornar este vídeo monográfico o mais agradável possível, já que difere dos usos e dos costumes de anotações dos textos impressos, dos atos de sublinhar, escrever nas bordas e margens feitos pelos leitores, que nesse caso incluem a própria banca examinadora. 
Em vídeo, quais seriam os recursos mais interessantes para este âmbito formal, acadêmico, e que precisa obter um consenso quanto à estética, de conforto ao leitor? Ainda não temos hipóteses de pesquisa suficientes para responder tal questão, apenas insights que nos geram mais dúvidas a serem divididas.

Quando temos dificuldade em elaborar um bloco de texto escrito, fazemos uma operação de pausar a leitura e escrever (ou reescrever), fazendo idas e vindas nas páginas. A experiência em elaborar e reelaborar vídeos, em fazer buscas, experimentar o processo de entendimento próprio do aluno surdo, de associação de ideias com registro próprio em Libras, particularizado e ao mesmo tempo cumprindo o princípio científico, as convenções de se universalizar uma técnica e/ou conteúdos neste tipo de material contínuo, filmado, e posteriormente sendo assistido, pela Banca Examinadora, nos dá ensejo a diversas demandas.

\section{Entre pares e línguas, objetos e processos: o que enfrentamos na consecução da monografia em Libras?}

Algumas idealizações estão em jogo em nossas discussões de equipe de monografia e, mesmo que estas não nos paralisem em nossas ações de orientação e defesas, precisamos de um certo grau de estranhamento para revê-las em grupo de pesquisa e nas próprias reuniões e fóruns do Departamento de Ensino Superior da instituição, pois estas ainda não são totalmente solucionáveis, restando a problematização entre pares para posterior amadurecimento.

As idealizações dos alunos surdos têm versado sobre: o tradutor-intérprete surdo como algo estável e a percepção de que existe uma única performance surda e não-surda típica da comunidade surda. Estes dois primeiros aspectos nos abrem espaço de atenção às trocas sobre a orientação para tradução e interpretação do ator-tradutor diante das câmeras, procurando respeitar outras camadas de atributos e características (de classe, gênero dentre outras) e que são sobrepostas à surdez. Também encontramos alunos surdos que supõem que a responsabilidade sobre a validação do glossário terminológico, da busca por vocábulos mais adequados em Libras, seja tarefa primeira da equipe de tradução e/ou do próprio orientador, em um ato extrínseco ao fazer-da-pesquisa.

As idealizações dos professores orientadores e da equipe de traduçãointerpretação atuantes em orientações de monografias em Libras versaram sobre algumas impressões errôneas, principalmente quanto ao uso das glosas. Nos incluímos, 
claramente, nesse equívoco enquanto novos atuantes de um curso bilíngue. Dentre eles, estão os seguintes:

1. Glosas prontas, pré-fixadas por parte do aluno ou do intérprete-tradutor resolveriam o papel do ator-tradutor. No entanto, a construção de glosas é processo da orientação de monografia em Libras na qual a autoria e os procedimentos aqui descritos neste artigo são atos postos em negociação por um longo período a cada aluno-orientando e a cada monografia realizada.

2. Não usar glossinais com alunos que dominam, relativamente, o português escrito assumindo o entendimento equivocado de que a passagem do português escrito para língua de sinais se daria, nesses casos, automaticamente na cabeça do aluno durante a sua performance de ator-tradutor, diante das câmeras de filmagem, ao ler o teleprompter.

As idealizações da Banca Examinadora revela-se pela desconfiança da influência do orientador que retiraria a autoria e as marcas do gesto do aluno-orientando, da apreensão conceitual. Porém, sabemos que é um caminho a ser construído em mão dupla: da construção intelectual-acadêmica e da atuação em vídeo-performance. Este duplo caminho demanda espectadores atentos, pares revisores e orientação adequada à monografia em Libras.

A estocagem de vídeos enfrenta episódios de resistência de administradores de repositórios em não viabilizar a disponibilidade de monografias em Libras, desconfiandose da já existente avaliação realizada em bancas de defesa, o que nos aponta para atos de violência simbólica na (re)testagem da clientela excluída academicamente, os surdos e a língua de sinais compartilhada também com não-surdos.

Há oscilações na valorização e desvalorização da produção acadêmica em língua de sinais e um reforço constante de que os alunos surdos precisariam se comprometer mais com o português escrito, quando sabemos que uma coisa independe da outra; a argumentação satisfatoriamente sustentada na língua de sinais é o que almeja-se com essa pesquisa; que os elementos constitutivos de uma gramática visual construam um produto hibrido que dê destaque e permanência a uma surdo-memória que, ainda, está sendo delegada a segundo plano. 


\subsection{As tensões presentes na equipe de orientação de monografia em Libras}

As características e atributos de uma ou mais performances surdas de traduçãointerpretação não podem ser desconsideradas no aprendizado, na feitura de um trabalho científico na língua de sinais. Igualmente não são habilidades que podem ser generalizadas ou atribuídas como naturais do surdo, porque requerem técnicas e informações teórico-práticas que precisam ser exercitadas, pois irão requerer estrutura gramatical e linguagem apropriadas da produção cinematográfica, de regras próprias de trabalhos registrados na forma escrita e transpostas para o universo da sinalidade, do design gráfico e do registro e edição em vídeo.

A interferência versus a mediação da equipe de orientação de monografia em Libras nos tem feito pensar sobre estas idealizações, ao estabelecer regras e metodologias, ao mesmo tempo preservando a autoria do aluno-orientando, balizando e investindo em um processo de formação que inclui a instrumentação prática para direção, roteirização e edição.

A desconfiança sobre o processo de orientação da monografia em Libras é permanente, pois é uma dupla desconfiança, da autoria como autenticidade e dos jogos de papéis, novamente, com outras polarizações que tentamos diluir com a elucidação do processo: (a) autenticidade versus atuação diante das câmeras, (b) tradução e (re)interpretação versus a fidelidade ao texto, (c) papel do copista versus o de autor.

As questões que esbarram na metodologia de ensino e da orientação de monografia para o aluno surdo e não-surdo também abrangem questões de formação permanente deste aluno bilíngue. Destacamos o problema da significação de textos em duas línguas, temáticas que servem para Libras e Língua Portuguesa: autenticidade, autoria, tradução, não fidelidade ao texto ou teoria-fonte. Ou então da língua-fonte ser, em sua maioria, em língua majoritária ou em apenas uma das línguas.

Mais profundamente, ter o intérprete como o único mediador de conceitos-chave não é a situação ideal, pois é uma tarefa que demanda o aluno-orientando e o professororientador em igual equilíbrio. Os textos-fonte sendo de domínio da equipe de orientação como um todo, incluindo a tradução-interpretação, permitem a exploração e a extração dos conceitos principais, a discussão mais consistente com a maturidade alcançada pelo grupo de pesquisa (tanto alunos quanto professores e intérpretes).

E em um movimento de circularidade abrangido por este artigo, podemos destacar que a Monografia em Libras requer a roteirização, direção e edição de vídeo com rigores 
apropriados à esfera formal e científica, ou seja, a um trabalho efetivamente acadêmico e voltado aos sujeitos bilíngues usuários da Libras e Língua Portuguesa. Um processo que ocorre desde o início em ambas as línguas, devido à quantidade maciça de textos-fonte em português.

Portanto, não é somente por se gerar um encarte em língua portuguesa que o DVD da monografia em Libras se define na esfera do bilinguismo, mas por todo o processo de orientação que se inicia com a leitura e reordenamento de construções do pensamento em duas línguas, do uso de glosas e glossinais, até o produto final em Libras, no formato vídeo, com outra aparência, estética e possibilidades de leitura de textos visuais. Esta experiência visual propicia ao surdo e ao não-surdo bilíngue desenhar ou (re)inventar a Educação Bilíngue no mundo acadêmico, sendo um dos desafios a produção de seus trabalhos científicos.

\section{Reflexões finais}

As lideranças surdas no DESU-INES, capitaneadas por professores e alunos surdos, lutaram pela implantação de regras específicas para a confecção de monografias em Libras. Primeiramente, começaram a construir as ideias através de sugestões debatidas em reuniões de professores, porém sem uma redação normativa. Em um crescente de ações no final do ano de 2014, com a entrada de um número próximo a trinta doutores recém-concursados, o Departamento ganha fôlego para redigir e validar algumas regras e normas, obtendo votação em Colegiado Departamental para a normalização do trabalho monográfico na modalidade Libras.

Com a orientação e defesa das primeiras monografias nesta modalidade, em 2015, este manual construído na colaboração entre surdos e não-surdos que se agregaram a esta tarefa, é alvo de uma revisão e ampliação quanto a forma e ao conteúdo a partir da prática de orientações de monografias em Libras ${ }^{12}$. Foram ampliadas as descrições sobre a formatação visual e inseridas sugestões de roteiro metodológico de modo a motivar novas

\footnotetext{
${ }^{12}$ Ampliação e revisão do Manual de Monografia em Libras - 2015.1 - Sugestão de roteiro metodológico após as primeiras defesas de monografias em Libras concebida esta metodologia para orientação por (em ordem alfabética) Ana Regina e Souza Campello, Cristiane Correia Taveira, Luiz Alexandre da Silva Rosado, Tanya Amara Felipe de Souza e outros colaboradores. A metodologia que se encontra discutida neste artigo é resultante do diálogo entre pesquisadores, as fontes bibliográficas que constam tanto neste artigo quanto do próprio Manual de Monografia em Libras e LP (DESU/INES, 2015), e também, é resultante do processo de orientação e da defesa de Monografias em Libras do DESU-INES. Site do INES onde se encontra o Manual na aba "Ensino Superior",
} 
equipes de orientação nesta modalidade. Esta nova versão do manual fora aprovada em Colegiado Departamental no primeiro semestre de 2015.

A Língua de sinais formal e acadêmica, o papel do aluno-orientando e a sua performance de ator-tradutor, o papel de seu professor-orientador, na execução da própria pesquisa em si, está diante de tensões quanto: (a) ao desenvolvimento de metodologias para orientação de monografias em Libras; (b) ao papel da equipe de tradução junto ao orientador de monografia em Libras; (c) ao uso de estúdio de filmagem que mescla recursos de mídia e educação e demandam roteirização, direção e edição de produtos; (d) ao formato semiprofissional para recursos, atores e cenários; (e) a defesa de uma gramática visual com convenções que se coadunam com a área de mídia-educação.

\section{Referências}

BAKER, C. Foundations of Bilingual Education and Bilingualism. 4. ed. Bristol, UK: Multilingual Matters, 2006.

BRASIL. Decreto $\mathbf{N}^{\mathbf{0}}$ 5.626, de 22 de dezembro de 2005. Regulamenta a Lei $\mathrm{n}^{\mathrm{o}} 10.436$, de 24 de abril de 2002, que dispõe sobre a Língua Brasileira de Sinais - Libras, e o art. 18 da Lei no 10.098, de 19 de dezembro de 2000.

BRASIL. Lei 10.436, de 24 de abril de 2002. Dispõe sobre a Língua Brasileira de Sinais (Libras) e dá outras providências.

BRASIL. Lei 12.319, de $1^{\circ}$ de setembro de 2010. Regulamenta a profissão de Tradutor e Intérprete da Língua Brasileira de Sinais - LIBRAS.

CAMPELLO, A. R. S.; CASTRO, N. P. Introdução da glosinais como ferramenta de tradução/interpretação das pessoas surdas brasileiras. Revista Escrita, Rio de Janeiro, n. 17, p. 1-14. 2013.

CASTRO, N. P. A tradução de fábulas seguindo aspectos imagéticos da linguagem cinematográfica e da língua de sinais. 2012. 165 fls. Dissertação (Mestrado em Estudos da Tradução) - Centro de Comunicação e Expressão. Programa de Pós-Graduação em Estudos da Tradução, Universidade Federal de Santa Catariana, Florianópolis, 2012. [Inclui DVD em Libras].

DESU/INES. Manual para normalização de trabalhos monográficos em Libras e língua portuguesa do DESU/INES. Disponível em: < http://www.ines.gov.br/images/desu/Manualde-Monografia-em-Libras-e-LP-2015.pdf> Acesso em: 10 out. 2018. 2015.

DONDIS, D. A. Sintaxe da linguagem visual. 3. ed. São Paulo: Martins Fontes, 2007.

FELIPE, T. A. O signo Gestual-visual e sua estrutura frasal na língua dos sinais dos Centros Urbanos do Brasil (LSCB). 1988. 104 fls. Dissertação (Mestrado em Linguística) Centro de Artes e Comunicação, Universidade Federal de Pernambuco, Pernambuco, 1988.

FELIPE, T. A. Bilinguismo e Educação Bilíngue: questões teóricas e práticas pedagógicas. Revista Forum, Rio de Janeiro, n. 25/26, p. 7-22, jan./dez. 2012. 
FLUSSER, V. A escrita - há futuro para a escrita? 1. ed. São Paulo: Annablume, 2010.

FLUSSER, V. O mundo codificado: por uma filosofia do design e da comunicação. 1. ed. São Paulo: Cosac Naify, 2013.

KARNOPP, L.; KLEIN, M.; LUNARDI-LAZZARIN, M. L. (Orgs.). Cultura Surda na contemporaneidade: negociações, intercorrências e provocações. 1. ed. Canoas: Ed ULBRA, 2011.

KITTLER, F. Mídias ópticas: curso em Berlim, 1999. 1. ed. Rio de Janeiro: Contraponto, 2016.

MAHER, T. de J. M. Hibridismos e linguagem: o inevitável diálogo entre Libras e a Língua Portuguesa no discurso do sujeito surdo. Forum - Instituto Nacional de Educação de Surdos, Rio de Janeiro, v. 25/26, p. 7-22, jan./dez. 2012.

MATEUS, S. Pode uma imagem ser um argumento? Revista Famecos, Porto Alegre, v. 23, n. 2, s/p, jun./ago. 2016.

OLIVEIRA, J. S.; SILVA, R. C. Equipe de tradução do curso de Letras Libras. In: QUADROS, R. M. de. (Org.). Letras LIBRAS: ontem, hoje e amanhã. 1. ed. Florianópolis: Ed. da UFSC, 2014. p. 93-111.

O’REILLY, T. What is web 2.0. Design Patterns and Business Models for the Next

Generation of Software. Disponível em: <http://oreilly.com/web2/archive/what-is-web20.html>. Acesso em: 20 out. 2018. 2005.

PERLIN, G.; MIRANDA, W. Surdos: o narrar e a política. Ponto de Vista, Florianópolis, n. 5, p. 217-226. 2003.

QUADROS, R. M. de; SOUZA, S. X. Aspectos da tradução/encenação na Língua de sinais Brasileira para um ambiente virtual de ensino: práticas tradutórias do curso de Letras Libras. In: QUADROS, R. M. de. (Org.). Estudos Surdos III. 1. ed. Petrópolis: Arara Azul, 2008. p. 170209.

SANTAELLA, L. Matrizes da linguagem e pensamento: sonora visual verbal: aplicações na hipermídia. 3. ed. São Paulo: Iluminuras: FAPESP, 2005.

SANTAELLA, L. Leitura de imagens. 1. ed. São Paulo: Editora Melhoramentos, 2012.

SANTAELLA, L. Navegar no ciberespaço: o perfil cognitivo do leitor imersivo. São Paulo: Paulus, 2004.

SOUZA, S. X. Performances de tradução para a Língua Brasileira de Sinais observadas no curso de Letras Libras. 2010. 174 fls. Dissertação (Mestrado em Estudos da Tradução) Centro de Comunicação e Expressão, Programa de Pós-Graduação em Estudos da Tradução, Universidade Federal de Sata Catarina, Florianópolis, 2010.

SOUZA, S. X. A norma surda de tradução em ambientes virtuais de ensino e aprendizagem: o caso do curso de LETRAS-LIBRAS da UFSC. In: CONGRESSO BRASILEIRO DE PESQUISA EM TRADUÇÃO E INTERPRETAÇÃO DE LÍNGUA DE SINAIS

BRASILEIRA, 2, 2010, Florianópolis. Anais... Florianópolis: UFSC, 2010. p. 1-7.

STONE, C. Toward a Deaf Translation Norm. 1. ed. Washington-DC, USA: Gallaudet University Press, 2009. 
STROBEL, K. As Imagens do outro sobre a Cultura Surda. Florianópolis, Editora UFSC, 2008.

THIOLLENT, M. Metodologia da pesquisa-ação. 18. ed. São Paulo: Cortez, 2011.

TAVEIRA, C. C.; ROSADO, L. A. da S. Por uma compreensão do letramento visual e seus suportes: articulando pesquisas sobre letramento, matrizes de linguagem e artefatos surdos. Espaço, Rio de Janeiro, n. 39, p. 27-42, jan./jun. 2013.

TAVEIRA, C. Por uma Didática da invenção surda: prática pedagógica nas escolas-piloto de educação bilíngue no município do Rio de Janeiro. 2014. 365 f. Tese (Doutorado em Educação) - Departamento de Educação, Pontifícia Universidade Católica do Rio de Janeiro, Rio de Janeiro, 2014.

TAVEIRA, C.; et al. Novas tecnologias na produção de monografias em Libras com alunos do INES: língua de sinais, performance surda e o uso do vídeo digital. In: ROSADO, L. A. da S.; FERREIRA, G. M. dos S. (Org.). Educação e Tecnologia: Parcerias Volume 4. Rio de Janeiro: Editora Universidade Estácio de Sá, 2015. p. 142-186.

Recebido em: 25 de outubro de 2018.

Aceito em: 07 de dezembro de 2018. 